\title{
Conference facilities as a key factor in the competitiveness of urban hotels: A case study of tódź (Poland)
}

https://doi.org/10.2478/ejthr-2020-0020

received April 30, 2020; accepted November 4, 2020

\begin{abstract}
The article aims to assess the competitiveness of hotels in Łódź on the meeting tourism (MICE) market based on an analysis of their conference facilities. The data was obtained from GUS statistics, reports on MICE tourism in Poland and as a result of own field research carried out in 2019. Exploratory data analysis was used in their development. The development of modern hotels in Łódź of higher categories with obligatory conference rooms has contributed to the diversification of the possibilities of organising MICE tourism by city hotels. The hotel's possession of conference facilities has become an important factor in building its competitive advantage. The analysis of hotel equipment with conference facilities, using the conference service capacity (CSC) index, turned out to be a sufficiently correct measure to illustrate the diversity of hotels' ability to compete in the MICE urban tourism market.
\end{abstract}

Keywords: Hotels; MICE tourism; Conference facilities; Competitiveness; Łódź

\section{Introduction}

As part of the restructuring of its economy, Łódź is trying to, inter alia, develop tourism, especially MICE travel services. The premises of this development are the following: 1) the geographical conditions in which the city and its region are situated (the central part of the country); 2) historical past, visible in the city's urban system, archi-

\footnotetext{
*Corresponding author: Joanna Bik, University of Lodz, Faculty of Geographical Sciences, Poland, 90-142 Lodz, Kopcinskiego 31, ORCID: 0000-0002-2186-142X, Email: joanna.bik@edu.uni.lodz.pl Anna Poreda, Andrzej Matczak, University of Lodz, Faculty of Geographical Sciences, Poland
}

tectural monuments and traditions (19th century industrial and residential buildings - factory owners' palaces, multifamily workers' houses, etc., as well as the remnants of the material and spiritual Polish, Jewish, German and Russian culture of the past); 3) the current state of the urban infrastructure (living and social conditions), which enables the city to perform metropolitan functions (educational, research, medical, cultural, etc. institutions). To take advantage of this potential, it is necessary to increase the city's hotel resources and their conference facilities. The aim of the article is an attempt to verify the view that equipping city hotels with conference facilities (in terms of size and structure) is the source of their competitive advantage.

\section{Literature Review}

\subsection{Meeting Tourism}

Meeting tourism, often referred to as MICE (Meetings, Incentives - motivational trips, Conventions - business events such as conferences, congresses, courses, Exhibitions - trade fairs and expositions), regards journeys made by company employees and other people as part of their job (Berbeka, Borodako, Klimek, Niemczyk, \& Seweryn, 2010). Thus, it is a highly diversified segment of tourism, which makes it difficult to formulate a generally accepted definition (Davidson \& Cope, 2003; Ladkin, 2002; Medlik, Dziedzic, \& Konieczna-Domańska, 1995; Mika, 2008; Sikošek, 2012). Practically, business tourism consists of the following: 1) convention tourism, including five types of meetings: congress, conference, convention, symposium and seminar; 2) trainings and courses held outside the permanent place of residence, which belong to the category of business and work-related trips; 3) convention events (e.g. conferences, seminars, etc.) combined with fairs and exhibitions; and 4) incentive trips (prizes, employee integration, etc.). Business travel 
usually takes place outside the tourist season; sometimes, trips last several days and are of great economic importance, because they involve larger expenses than other forms of tourism (amassed expenses of those who delegate and those who are delegated). They also require comprehensive service as regards the organisation of the event, the journey, stay, entertainment, etc. This means the involvement of numerous specialised firms (representing the accommodation, gastronomy and supplementary sectors), professional business travel providers, conference and congress organisers, carriers, incentive trips organisers, meeting/convention planners, local organising companies, audio-visual services providers, agencies seeking proper venues to hold business events, corporative or institutional clients, etc.). Business trips are also of considerable social significance, creating an opportunity to exchange information, knowledge and experience during meetings and scientific, professional, political or religious assemblies. All this contributes to the popularisation of economic, social and cultural innovations (Davidson \& Cope, 2003).

\subsection{Hotel Conference Facilities}

Equipping accommodation infrastructure, especially hotels, with conference amenities is a major issue in the analysis regarding the choice of business travel destinations. Organisers of such trips indicate that apart from the overall cost and spatial accessibility of such places, the availability of the highest standard hotels (the presence of conference rooms and good location), restaurants, exhibition spaces and accompanying services are important factors in choosing them as business meetings venues (Kachniewska, 2014). The research regarded the criteria used by business meeting organisers when choosing the venues, as well as the effort made by suppliers (including hotels) to attract them (Crouch \& Ritchie, 1997; Elston \& Draper, 2012; Oppermann \& Chon, 1997). What business meetings organisers took into account was the hotels and how they were equipped (Kachniewska, 2014; Ladkin, 2002; McCabe, 2002). Apart from the six indicated factors, the model of choosing a business meeting venue, developed by Crouch \& Ritchie (1997), includes the availability and standard of accommodation. Elston \& Draper (2012) point to the important role that accommodation facilities play in selecting business meeting venues. The quality and variety of accommodation alternatives are a priority. The importance and contribution of higher category hotels to the competitiveness and success of business tourism destinations are one of the most important
(Anas, Maddiah, Eizamly, N.A., \& Wee, 2020; Crouch, Del Chiappa, \& Perdue, 2019). Providing conference equipment for accommodation facilities incurs high costs, which means that conference hotels must be supported by public funding (Nelson, Baltin, \& Feighner, 2012). The reviews of research trends in business tourism presented so far (Getz \& Page, 2016) indicate that although business tourism cannot exist without properly equipped hotels, research in this particular field remains limited. Getz \& Page (2016) claim that business tourism studies are more strongly related to tourism than the hotel industry.

In Polish literature, the problem of providing tourism facilities (hotels included) with conference equipment has been discussed rarely. There have been few studies approaching these issues globally and only a small number of publications regarding individual topics. The problem of providing conference equipment for tourism facilities in Poland, based on the materials collected by the Central Statistical Office in 2009, was presented by Jagusiewicz (2013). Many authors writing about tourism MICE included the hotel conference equipment among several other issues they discussed (e.g. Jankowska, 2011; Sidorkiewicz, 2011). Research on MICE tourism in Łódź treated the aspect of hotel conference equipment as one of the many components of the city's potential for the development of this form of tourism (Napierała, 2014; Sylla, Chruściński, Drużyńska, Płóciennik, \& Osak, 2017). These particular problems have also been neglected in the analysis of the hotel sector development in Łódź.

MICE travel service is mostly provided by the existing tourism infrastructure. It includes the provision of accommodation, food, transport, culture, entertainment, recreation, information, etc. MICE tourism participants usually require a high standard of service; thus, they mainly use the highest standard hotels (generally three stars and higher). Around the world and in Poland, the majority of business meetings are held in hotels (Cieślikowski, 2010) that possess many attractive attributes for organising such events (Oppermann, 1996). In Poland, we can observe a systematically growing number of business meetings organised in hotels (Buczak, Gajewska, Książek, Węglarczyk, \& Zientalska, 2020; Celuch, 2016). Davidson \& Cope (2003) report that in Great Britain, 70\% of the conventions take place in hotels. They need to be equipped with conference facilities of appropriate size and standard. According to Polish legal regulations, only five- and four-star hotels must provide multi-purpose rooms: conference halls, club rooms, meeting rooms, etc. (Jagusiewicz, 2013; Sidorkiewicz, 2011). A significant element of this form of tourism is an attractive location and easy access to convention hotels by transport. 
Conference facilities in tourist accommodation establishments, especially hotels, consist of conference halls and proper technical equipment, supporting sessions and meetings. Depending on their size and standard, hotels offer different numbers of conference rooms: small buildings usually offer 1-4 rooms, medium-sized ones - up to 9 and larger ones -10 and more. Large hotels usually have several multi-functional conference rooms of varying size, capacity and purpose. They usually occupy a part of the hotel specifically intended for meetings and conferences, in the form of separate floors (McCabe, 2002). Depending on their size and function, the rooms can be divided into a conference and computer rooms (10-15 seats), seminar rooms (20-30 seats), small meeting rooms (up to 100 seats) and medium-sized and large halls (over 100 seats). Conference rooms may have different configurations, interior design and furniture arrangements, for example, the theatre, banquet or horseshoe setting. They also need to have good lighting, air-conditioning and additional spaces with an exposition and presentation area, coffee corners, rest places, etc. (Jagusiewicz, 2013).

Conference halls require a variety of technical equipment to make good-quality communication possible during meetings. Apart from an appropriate sound system (speakers, microphones), it is necessary to provide, projectors, boards, screens, computers, cameras, audio-video sets for video-conferences, as well as proper technical service. Conferences attended by international guests need rooms with a simultaneous translation system. Nowadays, it is also necessary to equip the rooms with a Wi-Fi.

Accommodation facilities and their surroundings should also provide recreation during breaks between sessions, as well as properly organise free time for conference participants (Knowles, 1998). This requires providing them with proper sports and recreational facilities, such as team sports grounds, swimming pools, bowling arcades, mini-golf, billiards tables, table tennis equipment, gyms, saunas, sun-beds, spa treatments, rehabilitation classes with an instructor (fitness, yoga, aerobics, exercise), etc. To increase the number of delegates and the incomes, hotels encourage conference and corporative meeting participants' family members and friends to take part in these events, offering them various amenities, such as nurseries, kids' clubs, etc. (McCabe, 2002). In Polish hotels, this trend shows in providing playrooms for children. Hotels that organise conferences must also be equipped with amenities for mobility-impaired people. They need to provide ramps, automatic doors, lifts and parking places adjusted to the needs of disabled persons.

Hotels draw substantial profits from providing gastronomic services for the conference guests and representa- tives. A key issue for the hotels is innovative conference lunches. Nowadays, they offer fresh fruit, herbal and fruit teas, etc., replacing traditional coffee and biscuits. At the beginning of the 21st century, in the USA, the cost of fruit and beverages made up $20 \%$ of the average conference budget (McCabe, 2002). To satisfy these requirements, hotels must be equipped with high-quality restaurants and cafes (with their own or outsourced catering), as well as bars, dining rooms and other eating facilities.

\section{Data and Methods}

Data on the equipment of tourist accommodation facilities (including hotels) with conference facilities in Poland is periodically collected by the Statistics Poland (so far for 2009, 2013 and 2017), and their results are made available in the 'Local Data Bank' (2020). This data provides information about the size, development rate and structure of the conference facilities at Polish hotels in individual cities and regions. The information regards the number of hotels offering conference rooms, their capacity and technical equipment (sound system, screens, computers, video, multimedia projectors, Wi-Fi, etc.), sports and recreational facilities (swimming pools, saunas, gyms, billiards, playrooms for children, etc.), as well as a range of amenities for mobility-impaired people (access ramps, properly adjusted doors, lifts, parking lots). In turn, the developed reports on MICE tourism in Poland (Buczak et al., 2020; Celuch, 2016) allow for obtaining fragmentary data concerning, equipping hotels with conference facilities. Together, this data allows for general recognition of trends in the development of conference facilities in all hotel facilities in Łódź. Hence, data on the size and structure of conference facilities at the level of individual hotels was collected during own Internet, telephone and field inquiries carried out in Eódź hotels in 2019 in terms of their location, standard, capacity and conference facilities, especially conference rooms and their capacity. During these meetings, information was also obtained about conference offers sent by hotels to organisers of MICE. The source materials collected in this way were developed using exploratory data analysis.

\section{Development of Hotels in tódź}

In Łódź, hotels have existed since the end of the 19th (the three-star Grand Hotel) and the early 20th century (the two-star Savoy and Polonia Palace hotels). They have 
a long tradition of accommodating travellers arriving in the city (Milewska \& Włodarczyk, 2004). Currently, they form a group of Łódź historical hotels, situated near Łódź Fabryczna Railway Station and, at the same time, in the city centre. During the interwar period (1919-1939), there were several hotels situated further from the centre, but after World War II, their hotel function was not restored (except for the Garrison hotel). New hotels (3) were not built until the 1970s. They were large, three-star hotels: Centrum Hotel opposite Łódź Fabryczna Railway Station (recently demolished), the equally large, three-star Światowit Hotel in the very centre of the city, as well as the twostar Mazowiecki Hotel, near Łódź Kaliska Railway Station. The return to the market economy resulted in the appearance of many new hotels after 1990. They were built along the southern and northern border of the city centre, in the zone adjacent to it and on the peripheries. After 2000, investors became more interested in adapting post-industrial and office buildings to serve as hotels (Cudny \& Rouba, 2010; Cybulska, 2011). Today, they are a visiting card of the city. Also, former workers' hotels were turned into hotels for the general public. Several new hotels were erected as well. Currently, the adapted post-industrial buildings and new hotels (mostly three- and four-star) match the world standards and are properly equipped for regular guests and business tourism. Łódź has never had a five-star hotel. As there had not been many traditional hotels in the city before 2004, in the newly built hotels, it was possible to implement the latest techniques of constructing buildings and their interiors, meeting specific MICE sector requirements.

Most hotels are located in the central part of Łódź, with its main tourist and cultural attractions, as well as administrative, business, entertainment, etc. institutions. A significant location factor for hotels in this city is still railway stations and transit roads (Matczak, 2020; Nalej, 2014; Włodarczyk, 2017). This is confirmed by the managers of Łódź hotels, who admit that it is the most important factor for the economy. The effect of a hotel is its location concerning the main roads, historical monuments, but also the fact of possessing additional facilities, such as restaurants and conference rooms. The spatial distribution of hotels in Eódź is presented in Figure 1.

Throughout its history, Łódź has always had modest numbers of hotel rooms to offer. In 2019, an average hotel in the city had over 95 rooms and about 170 beds. Among Polish metropolises (cities 6populated by over 0.5 million inhabitants), Łódź has for years come last as regards the number of hotels and their capacity. In 2019, the number of hotel beds and rooms per 1,000 inhabitants was 8.8 and 4.9, respectively (Table 1 ). Compared to many large Polish and West-European cities, it is still a very modest potential of hotel beds and rooms, which points to the need for further investments in the hotel industry. Presently, it is certain that the next five hotels will be built in Łódź (Arche Kaliska, Hampton by Hilton, Legs, Piotrkowska 94 Center Hotel, and a hotel in the Ghelamco complex), which are to be open in 2020-2021 (Zagrodnik \& Tencza, 2019). Moreover, there are plans to build the first five-star hotel in the city (L Hotel complex in Łagiewnicki Forest).

\section{Results}

\subsection{Conference Facilities in Hotels}

The majority of conference facilities found at the accommodation establishments in large Polish cities were located in hotels (Jagusiewicz, 2013). The situation is similar in Łódź, where about $80 \%$ of conference facilities were located in hotels. The trends in the dynamics of the growth of conference facilities in Łódźss accommodation base in the years 2009-2017 were therefore shaped by hotels. The data in Table 2 shows that the growth rate of hotel equipment with conference facilities was on average higher than their number and capacity.

In the years 2009-2017, Łódź was characterised by a high growth rate of hotel facilities equipped with conference rooms, the number of rooms and places in them. In Łódź, hotel facilities systematically increased the number of conference rooms. In 2009, there were on average 2.2 rooms per one tourist accommodation facility, and in 2017 - already 3.6 rooms. They were one of the largest conference rooms located in hotel facilities of large cities in the country. In 2009, the average conference room in Łódź had 68 seats. Eight years later, the average number of places in conference rooms per accommodation facility in Łódź was 91. Conference rooms, especially the large ones, were technologically well equipped. Nearly $25 \%$ of them had a sound system, wireless microphones and maintenance staff available, as well as multimedia projectors. Nearly half of the conference rooms had access to Wi-Fi at the hotel. Videoconference sets were less common - they were available in every tenth room.

In Łódź, similar to the remaining Polish metropolises, the majority of large and best-equipped conference halls were found in higher category hotels (Table 3). Technical equipment in modern hotels can be divided into basic and supplementary. The first category includes devices and amenities that are necessary to organise a professional conference: sound system, microphones, lighting, 


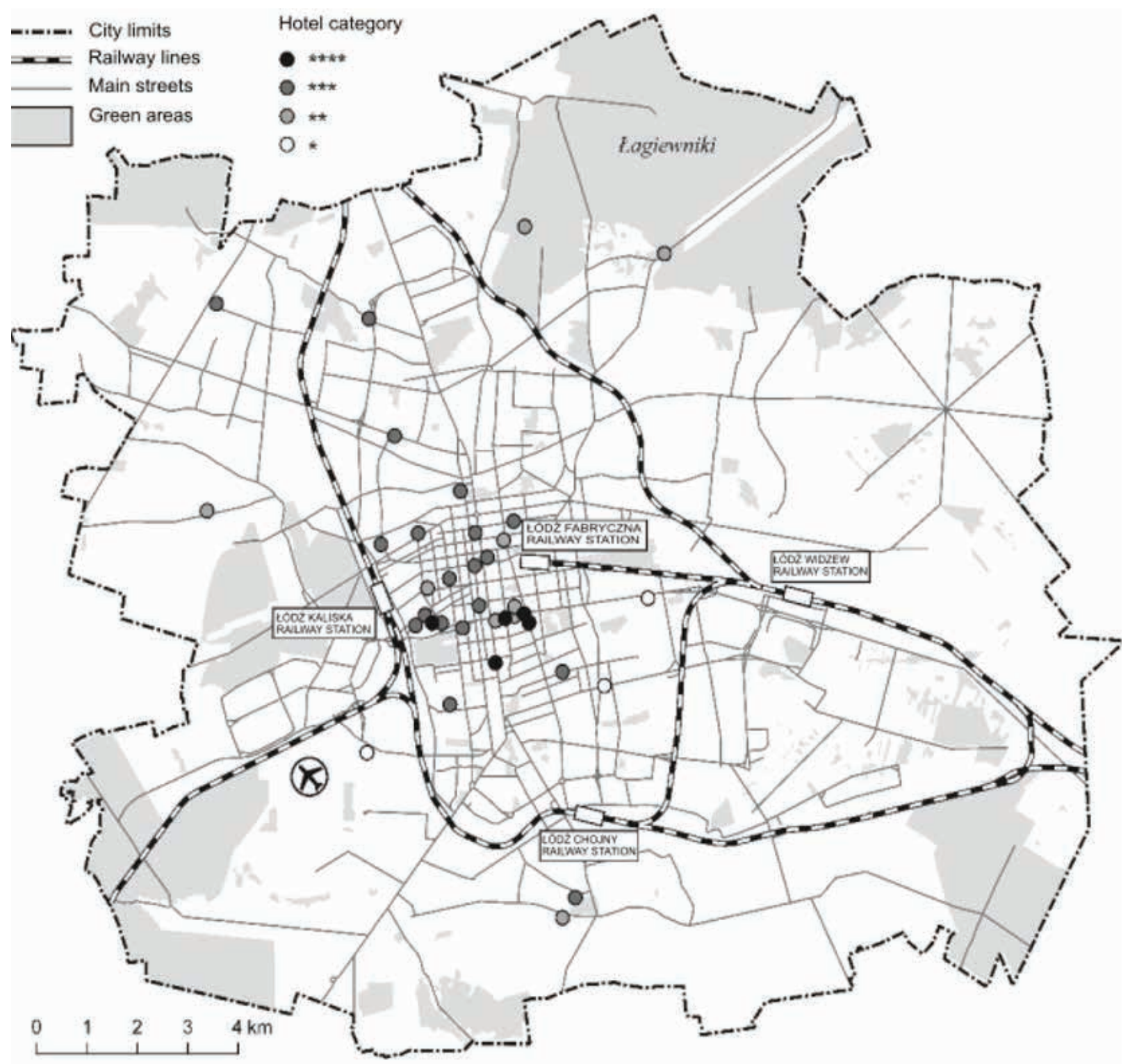

Figure 1: The spatial distribution of hotels in tódź by category.

Source: Own elaboration based on authors' field study conducted in 2019.

room-darkening, multimedia projector, Wi-Fi, air-conditioning and flipchart. The supplementary elements are those that make it easier to organise the event but are not essential - an executive table, rostrum, pointer, laptop, projector or cabins for simultaneous translation. As a rule, in contrast to the basic equipment, these items are extra paid.

More and more often, technical equipment determines the final choice of the event venue. Hence, Łódź fourstar hotels, which are equipped with all basic facilities, attach considerable significance to this issue. They are also trying to provide at least a part of the supplementary equipment, with the rostrum (71\%), executive table and pointers (57\% each) as the most important ones. When analysing individual elements of the technical equipment in hotels, we can observe that it is the four- and three-star hotels in Łódż that compete for organising events as part of business tourism.

Hotels providing conference service must also provide suitable gastronomic facilities in the form of restaurants, cafés, etc., which supply beverages and full board, organise banquets and coffee breaks between sessions. Higher-category hotels are obliged to have a restaurant; sometimes, they have more than one. The larger the number of luxurious hotels, the more hotel restaurants. The hotels usually have their brand bars and cafés as well. All higherand medium-category hotels in the five Polish metropolises possess recommended gastronomic facilities. Low- 
Table 1: Hotel rooms and beds in Łódź hotels per 1,000 inhabitants in 1990-2019

\begin{tabular}{llllll}
\hline Year & $\begin{array}{l}\text { Number of inhabitants } \\
\text { [in thousand] }\end{array}$ & Number of hotel beds & Number hotel rooms & $\begin{array}{l}\text { Number of hotel beds } \\
\text { per 1,000 inhabitants }\end{array}$ & $\begin{array}{l}\text { Number of hotel rooms } \\
\text { per 1,000 inhabitants }\end{array}$ \\
\hline 1990 & 848.3 & 1,832 & 1,067 & 2.2 & 1.3 \\
1995 & 823.2 & 1,874 & 1,128 & 2.3 & 1.4 \\
2000 & 798.4 & 2,353 & 1,443 & 2.9 & 1.8 \\
2005 & 767.6 & 2,104 & 1,335 & 2.7 & 1.7 \\
2010 & 730.6 & 3,536 & 2,076 & 4.8 & 3.8 \\
2015 & 701.0 & 4,906 & 2,758 & 7.0 & 3.9 \\
2017 & 690.4 & 5,008 & 2,748 & 7.2 & 4.0 \\
2019 & 682.7 & 5,979 & 3,341 & 8.8 & 4.9 \\
\hline
\end{tabular}

Source: Own elaboration based on 'Local Data Bank' (2020) and on authors' field study conducted in 2019.

Table 2: The growth rate in the number and capacity of hotels and their equipment with conference facilities and other amenities in Łódź in 2009-2017

\begin{tabular}{ll}
\hline Hotels and their equipment with conference facilities & $\begin{array}{l}\text { Growth index in the years 2009-2017 } \\
\mathbf{( 1 0 0 . 0 ~ i n ~ 2 0 1 9 )}\end{array}$ \\
\hline Number of hotels & 163.2 \\
Number of hotel rooms & 141.1 \\
Number of beds in hotels & 152.4 \\
Number of hotels with a conference room & 142.3 \\
Number of conference rooms & 177.6 \\
Number of seats in conference rooms & 238.9 \\
Rooms with sound system & 138.1 \\
Rooms with a wireless microphone & 156.2 \\
Rooms with technical services & 162.5 \\
Screen rooms & 160.9 \\
Rooms with a flipchart (dry-wipe board) & 205.3 \\
Rooms with other computer equipment & 210.7 \\
and Wi-Fi on the premises & \\
Hotels with sports and recreation facilities & 106.7 \\
Hotels equipped with facilities for the mobility impaired & 283.9 \\
\hline
\end{tabular}

Source: Own elaboration based on 'Local Data Bank' (2020).

er-category hotels do not always have their restaurants, but they usually provide catering.

One of the most popular supplementary services selected in hotels when organising business meetings is coffee breaks. A key issue for hotels is how to organise increasingly attractive and innovative coffee breaks, which will be long and well-remembered by the guests. Wishing to stand out from other similar places, hotels offer, for example, ecological or seasonal catering, based on local products (Nowakowska, 2014). Łódź hotels (both threeand four-star) do not diverge from global trends, making their coffee breaks increasingly attractive (Kozłowska, 2019). At the Focus Hotel, on top of the basic package, you can choose different extra packages: fit (e.g., energy chocolate bars, fruit mousses), energising, stimulating, sweet, vegetarian (e.g., fruit skewers, vegetables with dips) or sandwiches. At the Novotel Hotel, you can have a variety of menus: regional (e.g., potato salad with smoked meat, kvass), body cleansing (a cocktail made from melon, kiwi and pineapple), energising, bio (e.g., dried fruit, sweet corn and ginger mousse with whipped cream) or fruit. The Tobaco Hotel restaurant offers 'sweet tables' coffee breaks, 
Table 3: Technical equipment of the conference rooms in Łódź hotels, in 2019 (\%)

\begin{tabular}{lllllll}
\hline \multirow{2}{*}{ Hotel category } & \multicolumn{2}{l}{ Basic conference room equipment } & & & \\
& Sound system & Wireless microphones & Lighting & Room-darkening & Multimedia projector & Wi-Fi \\
\hline 1 star & 0 & 0 & 100 & 100 & 0 & 100 \\
2 stars & 50 & 50 & 80 & 70 & 70 & 80 \\
3 stars & 94 & 94 & 94 & 88 & 94 & 94 \\
4 stars & 100 & 100 & 100 & 100 & 100 & 100 \\
\hline
\end{tabular}

Source: Own elaboration based on authors' field study conducted in 2019.

fitting into the industrial atmosphere of the hotel and containing a wide range of snacks, such as chocolate-coated nuts, salty snacks, biscuits or sweets.

Hotels providing business tourism service are more and more often equipped with sports and recreation facilities, that is, swimming pools, gyms, saunas, spa and rehabilitation centres, including rooms for classes conducted by instructors (fitness, yoga, aerobics, gymnastics/ exercise), tennis tables, billiards tables, etc., as well as playrooms for children. Compared to other Polish metropolises, sports and recreation facilities resources in Łódź hotels were smaller, especially as regarded equipment necessary to provide spa and rehabilitation treatments, as well as classes with instructors. As for the swimming pools, gyms, saunas, table tennis and billiards tables, as well as playrooms for children, Łódź hotels presented a comparable level. Currently, a lot of attention is being paid to the problem of the hotels' preparedness to serve disabled guests, providing them with a range of amenities, such as ramps, automatic doors, special lifts and parking lots with places for mobility-impaired people, at a level comparable to the remaining metropolises in Poland.

\subsection{Conference Service Capability in tódź Hotels}

One of the measures used in the hotel industry is the one that defines conference service capability. It is expressed by the ratio of seats in multi-functional rooms to the number of beds in a given hotel. It provides information on whether all the participants of the events held at the hotel can be accommodated there. The value of the conference service capability (CSC) index $>1$ signifies a shortage of hotel beds, that is, lack of the possibility to provide accommodation to all the participants of the meeting, while CSC $\leq 1$ means that it is possible to provide accommodation to all the participants of the meeting, or even regular or unexpected guests (Milewska, Skrzypczyński,
\& Włodarczyk, 2004). Following the development of business tourism, hotels are increasingly focusing on the number and capacity of conference rooms, rather than on the possibility to put up all conference participants for the night.

In Łódź, newly opened hotels of higher categories were obligatorily equipped with conference rooms and other amenities necessary to support business tourism. This tendency continued in hotels in Eódź also in 2019. The CSC index was 2.23. However, it varied greatly from hotel to hotel. Only 13 of them (42\%) were able to spend the night of all conference participants; the rest did not have such an ability.

High-category hotels usually offer several conference rooms, including at least one multifunctional hall of high capacity (which can often be divided into smaller rooms). The actual ability of a hotel to provide service to conference guests is defined by the ratio of the number of seats in the largest hall (intended for the plenary session) to the number of hotel beds. The CSC index calculated in this way for individual hotels in Łódź in 2019 shows that 21 of them (68\%) are capable of accommodating all conference guests. This group included four-, three- and even twostar hotels.

\subsection{Conference Facilities of Hotels and Their Competitiveness}

The size and structure of hotel facilities in Eódź with conference facilities depended on the category of the hotel, its size expressed in the number of beds, affiliation to a chain and location within the city. They define the possibility of hotels to organise meetings and thus compete in the city's MICE tourism market.

In Łódź, the greatest potential for the organisation of MICE tourism was found mainly in chain hotels of higher (4-star) and medium (3-star) categories. They had the highest potential of both accommodation and conference 
Table 4: Potential of accommodation and conference services by hotels in Łódź, in 2019

\begin{tabular}{|c|c|c|c|c|c|c|c|c|c|}
\hline \multirow{2}{*}{$\begin{array}{l}\text { Hotel } \\
\text { category }\end{array}$} & \multicolumn{2}{|c|}{ Number of hotels } & \multicolumn{2}{|c|}{ Number of bed places } & \multicolumn{2}{|c|}{ Number of conference rooms } & \multicolumn{2}{|c|}{ Number of seats in conference rooms } & \multirow{2}{*}{$\begin{array}{l}\text { CSC } \\
\text { index }\end{array}$} \\
\hline & No. & $\%$ & No. & $\%$ & No. & $\%$ & No. & $\%$ & \\
\hline$\star \star \star \star \star ~$ & 7 & 21.1 & 2362 & 39.9 & 70 & 43.5 & 7911 & 52.6 & 3.35 \\
\hline$\star \star \star$ & 15 & 45.5 & 1907 & 32.2 & 68 & 42.2 & 5959 & 39.7 & 2.67 \\
\hline$\star \star$ and * & 11 & 33.3 & 1647 & 27.9 & 23 & 14.3 & 1159 & 7.7 & 0.70 \\
\hline Total & 33 & 100.0 & 5916 & 100.0 & 161 & 100.0 & 15029 & 100.0 & 2.62 \\
\hline
\end{tabular}

Source: own elaboration based on authors' field study conducted in 2019.

Table 5: Location of the potential for accommodation and conference services by hotels in Łódź, in 2019

\begin{tabular}{|c|c|c|c|c|c|}
\hline Part of the city & $\begin{array}{l}\text { Number of: } \\
\text { hotels }\end{array}$ & bed places & conference rooms & seats in conference rooms & CSC Index \\
\hline City centre & 11 & 2,710 & 58 & 4,030 & 1.49 \\
\hline 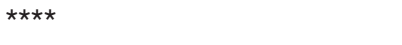 & 4 & 1,136 & 34 & 2,735 & 2.41 \\
\hline$\star \star \star ~$ & 3 & 600 & 16 & 1,222 & 2.04 \\
\hline ** and * & 4 & 974 & 8 & 398 & 0.41 \\
\hline $\begin{array}{l}\text { Closer neighbourhood from city } \\
\text { centre }\end{array}$ & 4 & 1,113 & 27 & 1,968 & 1.77 \\
\hline$\star \star \star \star *$ & 2 & 826 & 19 & 1,570 & 1.90 \\
\hline$\star \star \star *$ & 2 & 287 & 8 & 398 & 1.39 \\
\hline$\star \star$ and * & 0 & 0 & 0 & 0 & - \\
\hline $\begin{array}{l}\text { Further neighbourhood from city } \\
\text { centre }\end{array}$ & 8 & 1,289 & 39 & 4,994 & 3.87 \\
\hline 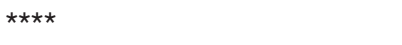 & 1 & 400 & 17 & 3,596 & 8.99 \\
\hline 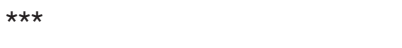 & 4 & 398 & 17 & 1,245 & 3.13 \\
\hline ** and * & 3 & 491 & 5 & 153 & 0.31 \\
\hline Periphery of city & 8 & 602 & 31 & 3,475 & 5.77 \\
\hline 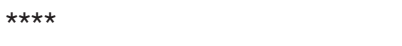 & 0 & 0 & 0 & 0 & - \\
\hline$\star \star \star$ & 5 & 436 & 24 & 2,928 & 6.72 \\
\hline ** and * & 3 & 166 & 7 & 547 & 3.29 \\
\hline Total & 31 & 5,714 & 155 & 14,467 & 2.53 \\
\hline
\end{tabular}

Source: Own elaboration based on authors' field study conducted in 2019.

rooms in the city (Table 4). The potential of the conference rooms held was significantly higher than that of their accommodation places. The CSC index for 4-star hotels averaged 3.35, and for 3-star hotels, it was at a slightly lower level of 2.67. On the other hand, lower-category hotels (1- and 2-star) played a complementary role, especially in terms of the number of accommodation places, as indicated by the CSC index value of 0.70 .

Hotels located in the city centre had the greatest potential for accommodation and conference facilities (Table 5). They consisted, to an almost equal extent, of higher and lower category hotels (belonging to hotel chains). These were usually large facilities (on average with more than 200 beds). However, their conference facilities varied. The highest-category hotels had the largest number and capacity of conference rooms, while the smaller-category hotels (generally small rooms with an average capacity of up to 50 seats). The comparison of the location of the accommodation stock and in conference rooms of hotels located in the city centre of Eódź justifies the conclusion that hotels of lower and partly also medium-sized categories constitute complimentary accommodation facilities 
for 4-star hotels with numerous and large-capacity conference rooms. These conclusions are confirmed by the value of the CSC index, which for 4-star hotels was 2.41, for 3-star hotels slightly less than 2.04, and for lower-category hotels - only 0.41 , indicating a large advantage in terms of the number of accommodation over conference rooms.

In the closer and more distant neighbourhood of the city centre, there was a similar potential in terms of the size and structure of hotel accommodation, but significantly higher in conference rooms than in the city centre. The possibility of supporting conferences by hotels located here, especially four-star ones, was higher (CSC = 4.20) than in the city centre. Three-star hotels located in the vicinity of the city centre $(\mathrm{CSC}=2.04)$ had fewer conference facilities. Hotels of lower categories had limited conference services (CSC $=0.31$ ).

On the other hand, in the peripheral zone of the city, there were only medium- and lower-category hotels with a total of a small number of beds, but with a high potential for conference rooms and places. Hotels located on the outskirts of the city were mainly focused on serving various forms of meetings. The CSC index for three-star hotels was 6.72, and for the lower categories, it was at the level of 3.29.

The analysis presented above suggests the following conclusions: 1) the potential of the conference facilities was concentrated in large hotels of higher and medium categories; hence, the increase in the size and category of the hotel indicated its higher competitiveness on the urban tourism market MICE; 2) higher-category hotels with a large number of beds, and at the same time, in conference rooms, they were concentrated in the city centre and its vicinity. This area of the city also concentrated hotels of lower categories with a relatively large number of beds and a low number of places in conference rooms, which indicated their location is complementary to hotels of higher categories. Hotels located on the outskirts of the city showed a clear advantage of the possibility of serving guests participating in various forms of meetings, rather than the possibility of providing them with accommodation. The indicated regularities were sufficiently and correctly illustrated by the CSC index, the value of which increased with the distance from the city centre.

\section{Discussion and Conclusions}

Being competitive lies in the ability of the destination to organise MICE effectively and efficiently. An important factor here is the potential of the hotel (standard, capac- ity, gastronomic, sports and recreation facilities, price, personnel, security, availability), adequately equipped with conference facilities (sufficient number, capacity and technical equipment of conference rooms, etc.). All destination selection models presented in the literature on the subject include the existing potential of hotels and their conference facilities. The models recognise the significance of resources (including hotels and their conference facilities) for a destination's ability to successfully organise a business event (Crouch et al., 2019; Crouch \& Ritchie, 1997; Ritchie \& Crouch, 2010). They also explain other important factors of destination competitiveness, which help cities to maintain a competitive advantage in the business events sector. These factors include the potential of hotels and their conference facilities. Lee \& Back (2005) point to the need for a more profound understanding of the relative role of each factor and its meaning about situational variables (including, among others, the hotel potential and equipping them with conference facilities). The analysis of the development of hotels in Eódź and their equipment with conference facilities confirms the importance and universality of this resource in the models of location and organisation of MICE.

Hotel conference facilities should always be considered in the context of consequences for their overall activity. Possessing conference facilities should give a hotel a competitive advantage on the market (Knowles, 1998). In highly competitive market conditions, such facilities require continuous development and improvement. A hotel will stay on the business tourism market only if it systematically creates and implements new products and services, including conference facilities. Hotels may use two, mutually complementary strategies - innovation and diversification of the product. Nowadays, it is not enough to possess conference rooms equipped with modern technology. They must be accompanied by high-quality hotel gastronomy, respecting the rules of healthy eating. Until recently, sports and recreation centres (bio-regeneration) had been an innovation in hotels. Nowadays, this facility has become a requirement that the hotel has to provide to offer business tourism services (Knowles, 1998). Hotels must introduce new equipment, based on the latest technologies. And, they have to provide amenities for the disabled. Business tourism organisers and consumers see conference facilities as an integral part of the package of hotel products and services. Hotels may draw profits from the conference facilities they possess, not only by providing business tourism service but also by renting their conference rooms, restaurants and sports and recreation facilities (bio-regeneration centres) to local firms and inhabitants. Hotel conference facilities may be an effective 
marketing tool, improving the hotel's image and increasing the number of rented rooms and business guests, which enhances its financial effectiveness. In Łódź, such hotels are still a novelty, which makes it easier for them to (for a short time) compete on the local and national markets. For developing economies, investing in better basic accommodation infrastructure (especially hotels equipped with modern conference facilities) means more effective competition (Crouch, 2011). This is the present situation of hotels in Łódź.

The assessment of the service capabilities of tourism accommodation facilities (including hotels) requires appropriate statistical data for individual administrative units. In Poland, such statistics (periodically every four years) have been available since 2009, but aggregated at the level of the total number of accommodation facilities in district and voivodships. It points to the gaps in the potential of the entire hotel base and their equipment with conference facilities in destination places (districts, cities with district status, regions). The high degree of aggregation of data limits the possibility of conducting broader analyses. The available reports of MICE tourism in Poland, as well as the literature on the subject, provide fragmentary data on the equipment of hotels with conference facilities. Acquiring primary data through individual field inventories is limited due to high costs. Such a method of data acquisition is possible at the level of a single city or a relatively small area, but not a whole region or country. Further studies must be improved as regards access to adequate statistical materials, especially for categorised hotels. At present, the available statistical resources regarding hotels allow us to recognise current trends.

Another limitation is the indexes based on these statistics. As regards the assessment of service provided by hotels in business tourism, the analysis presented in the article points to sufficient usability of the CSC index, calculated as the ratio of the overall capacity of conference rooms to the hotel's ability to accommodate all conference participants. A significantly better result regarding the evaluation of conference service was achieved based on the CSC index, which referred to the capacity of the largest conference room in a given hotel (intended for plenary sessions). The CSC index calculated in this way reflected the possibility of accommodating all conference participants in the hotel more realistically.

The potential of the conference facilities owned by the hotel shows its competitive potential on the MICE tourism market. In this respect, higher-class hotels located in the city centre and its vicinity were more competitive. Their potential for accommodation was complemented by medium- and lower-category hotels. On the other hand, peripherally located medium- and lower-category hotels specialised in servicing various forms of meetings, having large conference facilities with little potential for accommodation. Therefore, no clear impact of the distance from the city centre on the size and structure of hotel conference facilities was observed. In this respect, the features of the urban environment turned out to be more important. The city centre and its neighbouring areas turned out to be the main factor favouring the location of higher-class hotels, well equipped with conference facilities. In turn, the peripheral areas of the city had less significant hotel facilities than in the centre, but with large conference facilities. The impact of the distance from the city centre on the hotel equipment with conference facilities was not clear, as was the case with the prices of hotel services (Adamiak \& Napierala, 2013; Napierała \& Adamiak, 2014).

Analysing the development of hotels and their equipment with conference facilities in Łódź, one can conclude that the possibilities of hotels serving MICE tourism are increasing. It has been confirmed by research conducted in 2009-2016, which points to the growing share of hotels in the reception of tourists in Łódź (Włodarczyk, 2011, 2016). The growing use of hotel accommodation while participating in business tourism in Łódź is connected with the increase in the number and capacity of higher-category hotels and their conference facilities.

\section{Bionotes}

Joanna Bik is a doctoral student at the University of Lodz in Poland. Her research interests are related to religious tourism, the use of accommodation in religious tourism and conference tourism.

Anna Poreda is a doctoral student and a research assistant at the Faculty of Geographical Sciences at the University of Lodz in Poland. Her research interests are related to culinary tourism, culinary heritage, gastronomic products and gastronomy in hotels.

Andrzej Matczak is a professor at the Faculty of Geographical Sciences at the University of Lodz in Poland. His research interests are related to urban and tourism geography: city's function, tourism (including tourists' flows and hotel industry) and the phenomenon of second homes.

\section{References}

[1] Adamiak, M., \& Napierala, T. (2013). Przestrzenne zróżnicowanie cen usług noclegowych w tódzkim Obszarze 
Metropolitalnym [Geographic differences in prices of accommodation services in the Łódź Metropolitan Area]. Prace Geograficzne, (134), 37-50. https://doi.org/10.4467/2 0833113PG.13.014.1260

[2] Anas, M. S., Maddiah, N. A., Eizamly, N. U. E. N., N.A., S., \& Wee, H. (2020). Key success factors toward MICE industry: A systematic literature review. Journal of Tourism, Hospitality \& Culinary Arts, 12(1), 188-221.

[3] Berbeka, J., Borodako, K., Klimek, K., Niemczyk, A., \& Seweryn, R. (2010). Turystyka MICE w Krakowie w roku 2010. Raport końcowy [MICE tourism in Kraków in 2010. Final report]. Retrieved 15 April 2020, from http://impactkrakow. com/wp-content/uploads/Turystyka-MICE-w-Krakowie-w2010-roku.pdf

[4] Buczak, T., Gajewska, K., Książek, A., Węglarczyk, J., \& Zientalska, D. (2020). Przemysł spotkań i wydarzeń w Polsce: Raport 2020 [Meeting and event industry in Poland: Report 2020]. Retrieved 15 April 2020, from https://www.pot.gov.pl/ attachments/article/148/RAPORT 2020_PL_14.09.pdf

[5] Celuch, K. (2016). Przemyst spotkań i wydarzeń w Polsce: Raport 2016 [Meeting and event industry in Poland: Report 2016]. Retrieved 15 April 2020, from http://download. poland-convention.pl/data/PDF/PrzemyslSpotkanwPolsce2016.pdf

[6] Cieślikowski, K. (2010). Hotele jako kluczowe podmioty w procesie ksztaltowania oferty na rynku turystyki konferencyjnej [Hotels as key entities in the process of creating the offer on the conference tourism market]. Zeszyty Naukowe Wyższej Szkoły Informatyczno-Ekonomicznej w Warszawie, 24, 7-22.

[7] Crouch, G. I. (2011). Destination Competitiveness: An Analysis of Determinant Attributes. Journal of Travel Research, 50(1), 27-45. https://doi.org/10.1177/0047287510362776

[8] Crouch, G. I., Del Chiappa, G., \& Perdue, R. R. (2019). International convention tourism: A choice modelling experiment of host city competition. Tourism Management, 71, 530-542. https://doi.org/10.1016/j.tourman.2018.10.002

[9] Crouch, G. I., \& Ritchie, J. R. B. (1997). Convention Site Selection Research: A Review, Conceptual Model, and Propositional Framework. Journal of Convention \& Exhibition Management, 1(1), 49-69. https://doi.org/10.1300/ J143v01n01_05

[10] Cudny, W., \& Rouba, R. (2010). Funkcja hotelarska w kompleksie Manufaktury w todzi na przykładzie hotelu Andel's [Hotel function in the Manufaktura complex in Łódź: case of the Andel's hotel]. Turystyka i Hotelarstwo, 15, 145-158.

[11] Cybulska, K. (2011). Przystosowanie obiektów zabytkowych do petnienia funkcji hotelarskiej - przykład todzi [Adaptation of historic buildings to hotel function - the case of tódź]. Turystyka i Hotelarstwo, 17, 105-135.

[12] Davidson, R., \& Cope, B. (2003). Business Travel. Conferences, Incentive Travel, Exhibitions, Corporate Hospitality and Corporate Travel. Harlow: Pearson Education Limited.

[13] Elston, K., \& Draper, J. (2012). A Review of Meeting Planner Site Selection Criteria Research. Journal of Convention \& Event Tourism, 13(3), 203-220. https://doi.org/10.1080/1547 0148.2012.715269
[14] Getz, D., \& Page, S. J. (2016). Progress and prospects for event tourism research. Tourism Management, 52, 593-631. https://doi.org/10.1016/j.tourman.2015.03.007

[15] Jagusiewicz, A. (2013). Zaplecze konferencyjne w turystycznych obiektach noclegowych w Polsce [Conference Facilities in Tourist Accommodation in Poland]. Problemy Turystyki i Rekreacji, 1, 27-48.

[16] Jankowska, A. (2011). Convention Bureau Szczecin jako nowe biuro turystyki biznesowej na polskim rynku [Convention Bureau Szczecin as a New Business Tourism Office in the Polish Market]. Zeszyty Naukowe Uniwersytetu Szczecińskiego. Ekonomiczne Problemy Turystyki, 626(15), 53-64.

[17] Kachniewska, M. (2014). Czynniki wyboru lokalizacji konferencji i kongresów w ocenie polskich organizatorów [The determinants of conference and congress site location in the opinion of Polish operators]. In K. Celuch (Ed.), Zarządzanie i organizacja w przemyśle spotkań w Polsce. Teoria i praktyka (pp. 37-49). Warszawa: Szkoła Gtówna Turystyki i Rekreacji.

[18] Knowles, T. (1998). Hospitality management: An introduction (2nd ed.). London: Pearson Longman.

[19] Koztowska, A. (2019). The gastronomic product of Łódź hotels. Turyzm/Tourism, 29(1), 37-45. https://doi. org/10.2478/tour-2019-0004

[20] Ladkin, A. (2002). Convention tourism: international research and industry perspectives. In K. Weber \& K. S. Chon (Eds.), Research issues and challenges for the convention industry (pp. 101-118). Binghamton: Haworth Hospitality Press.

[21] Lee, M. J., \& Back, K.-J. (2005). A Review of Convention and Meeting Management Research 1990-2003. Journal of Convention \& Event Tourism, 7(2), 1-20. https://doi. org/10.1300/J452v07n02_01

[22] Local Data Bank. (2020). Retrieved 21 March 2020, from https://bdl.stat.gov.pl/BDL/start

[23] Matczak, A. (2020). Zmiany w wielkości i użytkowaniu hoteli $w$ todzi [Changes in the size and use of hotels in tódź]. In R. Szkup (Ed.), Turystyczna baza noclegowa województwa tódzkiego (pp. 127-147). tódź: Wydawnictwo Uniwersytetu tódzkiego. https://doi.org/10.18778/8142-645-9.05

[24] McCabe, V. S. (2002). Convention hotels in Australia: Trend and issues. In K. Weber \& K. S. Chon (Eds.), Research issues and challenges for the convention industry (pp. 185-199). Binghamton: Haworth Hospitality Press.

[25] Medlik, S., Dziedzic, E., \& Konieczna-Domańska, A. (1995). Leksykon podróży, turystyki, hotelarstwa [Lexicon of travel, tourism and hospitality]. Warszawa: Wydawnictwo Naukowe PWN.

[26] Mika, M. (2008). Formy turystyki biznesowej. In W. Kurek (Ed.), Turystyka (pp. 300-313). Warszawa: Wydawnictwo Naukowe PWN.

[27] Milewska, M., Skrzypczyński, M., \& Włodarczyk, B. (2004). Mierniki jako ważny element nauczania hotelarstwa [Measures as a significant element of hospitality education]. Turystyka i Hotelarstwo, 5, 107-133.

[28] Milewska, M., \& Włodarczyk, B. (2004). Historia hotelarstwa $w$ Łodzi [History of hotel industry in Łódź]. Turystyka i Hotelarstwo, 5, 55-93.

[29] Nalej, M. (2014). Rozmieszczenie obiektów noclegowych w Łodzi w 2013 roku w świetle miar centrograficznych [Location 
of accommodation places in Łódź 2013 in the light of centroid measures]. Acta Universitatis Lodziensis. Folia Geographica Socio-Oeconomica, 16(1), 133-148.

[30] Napierata, T. (2014). MICE tourism in Łódź Metropolitan Area. Retrieved 15 April 2020, from http://schedule.edu. $\mathrm{pl} / 24$ hours/subject-description/

[31] Napierała, T., \& Adamiak, M. (2014). Odległość od centrum miasta jako determinanta cen usług hotelowych [Distance from the city centre as a determinant of hotel room rates]. Studia Oeconomica Posnaniensia, 2(3), 41-54.

[32] Nelson, R. R., Baltin, B., \& Feighner, B. (2012). Public-Private Financing Structures Used in the United States to Develop Convention Hotels. Journal of Convention \& Event Tourism, 13(2), 135-146. https://doi.org/10.1080/15470148.2012. 684305

[33] Nowakowska, A. (2014). Eko innowacyjne rozwiązania w obiektach i miejscach spotkań. In A. Grzegorczyk, J. Majewski, \& S. Wróblewski (Eds.), Innowacje w przemyśle spotkań (pp. 161-183). Warszawa: Wyższa Szkoła Promocji.

[34] Oppermann, M. (1996). Convention Cities: Images and Changing Fortunes. Journal of Tourism Studies, 7(1), 11-19.

[35] Oppermann, M., \& Chon, K.-S. (1997). Convention participation decision-making process. Annals of Tourism Research, 24(1), 178-191. https://doi.org/10.1016/ S0160-7383(96)00049-7

[36] Ritchie, J. R. B., \& Crouch, G. I. (2010). A model of destination competitiveness/sustainability: Brazilian perspectives.
Revista de Administração Pública, 44(5), 1049-1066. https:// doi.org/10.1590/S0034-76122010000500003

[37] Sidorkiewicz, M. (2011). Turystyka biznesowa [Business tourism]. Warszawa: Difin.

[38] Sikošek, M. (2012). A Review of Research in Meetings Management: Some Issues and Challenges. Academica Turistica, 5(2), 61-76.

[39] Sylla, M., Chruściński, J., Drużyńska, P., Ptóciennik, P., \& Osak, W. (2017). Opportunities and limitations for MICE tourism development in Łódź. Turyzm/Tourism, 25(2), 117-124. https://doi.org/10.1515/tour-2015-0011

[40] Włodarczyk, B. (Ed.). (2011). Ruch turystyczny w todzi i województwie tódzkim w 2010 roku [Tourism in tódź and tódzkie voivodeship in 2010]. Łódź: Regionalna Organizacja Turystyczna Województwa Łódzkiego.

[41] Włodarczyk, B. (Ed.). (2016). Ruch turystyczny w todzi i województwie tódzkim w 2016 roku [Tourism in tódź and tódzkie voivodeship in 2016]. Łódź: Instytut Geografii Miast i Turyzmu Uniwersytetu tódzkiego.

[42] Włodarczyk, B. (2017). Hotels in Łódź city space. Turyzm/Tourism, 25(2), 61-72. https://doi.org/10.1515/ tour-2015-0006

[43] Zagrodnik, B., \& Tencza, K. (2019). Rynek hotelowy w Łodzi [Hotel market in Łódź]. Retrieved 15 April 2020, from https:// uml.lodz.pl/files/public/dla_biznesu/investlodz/wh_raport_ lodz_v19_web.pdf 